\title{
ADDITION OF GREEN BANANA FLOUR TO INSTANT NOODLES: RHEOLOGICAL AND TECHNOLOGICAL PROPERTIES
}

\author{
Adição de farinha de banana verde em macarrão instantâneo: \\ propriedades reológicas e tecnológicas
}

\author{
Maria Gabriela Vernaza ${ }^{1}$, Márcia Arocha Gularte ${ }^{2}$, Yoon Kil Chang ${ }^{3}$
}

\begin{abstract}
Nowadays, there is considerable concern about the consumption of high fat and low fiber foods. The objective was to develop instant noodles (IN) with functional properties by adding $10 \%$ green banana flour (GBF), and determine the effect of this on the dough rheological properties. Noodles were obtained through sheeting, steaming and frying process. The IN were characterized for their moisture, fat, resistant starch (RS), texture and color. The proximate composition showed that GBF was rich in ash (3.16\%), fiber $(8.88 \%)$ and RS $(45.70 \%)$, being an attractive raw material for the production of functional IN. When $10 \%$ GBF was added, rheological properties of dough changed because of dilution of gluten, making it weaker, but with enough extensibility and elasticity for functional IN production. The addition of $10 \%$ GBF significantly reduced the oil content in all the frying times, when compared to the control noodles, increasing also RS content. Ban10 noodles showed a lower $L^{*}$ value (78.12), indicating a darker color than the control noodles (92.36). In analyzing the firmness of Ban10 noodles, a decrease was observed due to dilution of gluten. However, Ban 10 noodles showed a better nutritional profile due to the increase in ash and dietary fiber contents. In conclusion it can be affirmed that Ban10 noodles can be considered as functional IN, due to the presence of fiber (5.79\%) and RS (3.98\%) contents in the final product.
\end{abstract}

Index terms: Functional noodles, resistant starch, oil absorption.

\section{RESUMO}

Atualmente, existe uma preocupação com relação ao consumo de alimentos com alto teor de gordura e baixo em fibras. Neste trabalho, objetivou-se desenvolver macarrão instantâneo com propriedades funcionais através da adição de 10\% de farinha de banana verde (FBV) e determinar os efeitos nas propriedades reológicas da massa. Os macarrões instantâneos foram obtidos por processos de laminação, cozimento a vapor e fritura. Os macarrões foram caracterizados quanto à umidade, gordura, amido resistente, textura e cor. A composição centesimal mostrou que a FBV contém alto teor de cinzas $(3,16 \%)$, fibras $(8,88 \%)$ e amido resistente $(45,70 \%)$, sendo uma matéria-prima interessante na produção de macarrão instantâneo funcional. Quando adicionado 10\% de FBV à farinha de trigo as propriedades reológicas da massa foram alteradas, em razão da diluição do glúten, tornando-o mais fraco, mas com extensibilidade e elasticidade suficiente para a produção de macarrão instantâneo funcional. A adição de FBV reduziu significativamente o teor de gordura em todos os tempos de fritura e aumentou o teor de amido resistente, quando comparado ao macarrão instantâneo controle. Os macarrões Ban10 apresentaram um menor valor no parâmetro $L^{*}(78,12)$, indicando uma coloração mais escura do que o controle (92,36). A adição de FBV diminuiu a firmeza dos macarrões, em decorrência da diluição do glúten. No entanto, os macarrões Ban10 apresentaram um melhor perfil nutricional, pelo aumento no teor de cinzas e fibra alimentar total. Em conclusão, pode ser afirmado que os macarrões Ban10 podem ser considerados funcionais, em razão do teor alto de fibra $(5,79 \%)$ e de amido resistente $(3,98 \%)$.

Termos para indexação: Macarrão instantâneo funcional, amido resistente, absorção de gordura.

(Received in may 3, 2011 and approved in june 27, 2011)

\section{INTRODUCTION}

According to a ABIMA survey (2005), the instant noodles market has been growing at rates of $5 \%$ per year. This increase in production and consumption of instant noodles can be attributed to their low cost and convenience, and also because they are quick and easy to prepare. However, since instant noodles are a deep-fried product, they contains high levels of residual oils, and nowadays there is great concern with respect to the health and consumption of high fat content products. Therefore, there is a need to develop healthier products with functional appeal.

Resistant starch (RS) is a starch fraction that does not provide glucose to the body and resists enzymatic digestion in the small intestine, but can be fermented in the colon by bacterial microflora producing mainly gas and short chain fatty acids. Due to these characteristics,

\footnotetext{
1Universidade Estadual de Campinas/UNICAMP - Departamento de Tecnologia de Alimentos - Rua Monteiro Lobato - 80 - Cx.P. 6121 - $13083-862$ Campinas - SP - Brasil - gabriela.vernaza@gmail.com

2Universidade Federal de Pelotas/UFPel - Departamento de Ciência dos Alimentos - Pelotas - RS - Brasil

${ }^{3}$ Universidade Estadual de Campinas/UNICAMP - Departamento de Tecnologia de Alimentos - Campinas - SP - Brasil
}

Ciênc. agrotec., Lavras, v. 35, n. 6, p. 1157-1165, nov./dez., 2011 
the effects of RS are comparable to those of dietary fiber and it is therefore usually considered as a component of this fraction (CHAMP; FAISANT, 1996).

The production of green banana flour presents high variability for the food industry, mainly in bakery products, dietary products and infant foods, being a rich source of $\mathrm{RS}$ and mineral salts such as potassium, iron, calcium, magnesium and sulfur (FASOLIN et al., 2007, BORGES et al., 2009).

The aim of this paper was to develop instant noodles with functional properties by adding $10 \%$ green banana flour (GBF). Some other objectives were: characterize the GBF, study the effect of adding $10 \% \mathrm{GBF}$ on the rheological properties of the dough and analyze the RS content present in the GBF and during all the stages of the instant noodle production.

\section{MATERIAL AND METHODS}

\section{Materials and chemicals}

The raw materials used in this study were: wheat flour (Propan 50 for noodle production), supplied by the Bunge company (São Paulo, Brazil), commercial green banana flour (GBF), provided by Belo Vale Indústria de Alimentos Ltda. (São Paulo, Brazil), and palm oil (São Paulo, Brazil). Wheat flour and GBF were maintained at $4^{\circ} \mathrm{C}$ until experiments begun. Alpha-amylase type VI-B from the porcine pancreas (EC 3.2.1.1), pepsin from the porcine gastric mucosa (EC 3.4.23.1) and amyloglycosidase from Aspergillus niger (EC 3.2.1.3) were obtained from Sigma Co. All other reagents and chemicals were of analytical grade.

\section{Methods}

\section{Physical and physicochemical analysis}

The raw materials were characterized for their proximate composition following AACC methods (2000) and they include: (i) moisture, according to method 44-15, (ii) fat, according to method 30-10, (iii) protein, according to method 46-13, (iv) ash, according to method 08-10, and (vi) carbohydrates by difference, and (vii) total dietary fiber according to method 991.43 (AOAC 1995).

The raw materials were also analyzed for their RS content according to the enzymatic methodology proposed by Goñi et al. (1996); for their color (luminosity), which was measured instrumentally using a Hunter Lab colorimeter; for their viscoamylographic properties using a Rapid Visco Analyser (RVA), according to the official method 162 (ICC, 1995), using
Standard Program 1 and finally for their format using polarized light microscopy.

In pre-tests, when more than $10 \%$ of GBF was added it was impossible to produce any viscoelastic dough, and therefore it was decided to use this maximum limit of GBF for noodle production. The mixture Ban 10 (wheat flour with the addition of $10 \% \mathrm{GBF}$ ) was also characterized for its color and viscoamylographic properties.

\section{Rheological properties}

Finally, the wheat flour and Ban10 mixture were characterized for their rheological properties: (i) farinograph, according to method 54-21 (AACC, 2000) using a Brabender Farinograph (Germany) and (ii) extensograph, according to method 54-10 (AACC, 2000) using a Brabender Extensograph (Germany).

\section{Making instant noodles}

To obtain the instant noodles, two formulations were processed: 1 ) control (wheat flour $+2 \%$ salt and $0.22 \%$ guar gum) and 2) test - Ban 10 (wheat flour $+10 \%$ $\mathrm{GBF}+2 \%$ salt and $0.22 \%$ guar gum). The sodium chloride and guar gum were first dissolved in the water used for noodle making $(35 \%)$. The wheat flour $(1000 \mathrm{~g})$ was then mixed with the GBF for $15 \mathrm{~min}$ in a regular mixer, the brine solution was added and the sample was mixed in a pin mixer (Piuno Nuova, Italy) for $10 \mathrm{~min}$. Then the dough was divided into three to evaluate three replicates of the process. The dough was then passed through the rollers of the noodle machine (Piuno, Nouva, Italy) with a $4 \mathrm{~mm}$ gap, and the noodle dough sheet folded and put through the sheeting rollers. The folding and sheeting was repeated twice, and the sheeted dough then allowed to rest for 10 minutes before putting it through the sheeting rollers a further six times with a progressively smaller gaps until a final gap of $1.20 \mathrm{~mm}$ was reached. The final noodle dough sheet was then cut with the noodle cutting rolls (Piuno Nuova, Italy) with $0.9 \mathrm{~mm}$ grooves.

The fresh noodles were steamed at atmospheric pressure for $6 \mathrm{~min}$ (until the complete gelatinization of the starch) in a steam oven (Prática, Brazil), and then $50 \mathrm{~g}$ of the steamed noodles were weighed and put into a stainless steel covered basket and immersed into hot oil $\left(150 \pm 3^{\circ} \mathrm{C}\right)$. The noodles were fried in palm oil for 30, 60, 90 and 120 seconds, to determine the moisture content loss, fat absorption and RS degradation during the frying process. At the end of each frying time, the basket was raised, the samples removed from the basket and placed on paper towels under a fan to remove excess fat. 


\section{Characterization of the instant noodles}

The noodles obtained with both formulations (control and Ban10) and fried for 30, 60, 90 and 120 seconds were characterized for their oil absorption according to method 30-25 (AACC, 2000) and moisture content according to method 44-15 (AACC, 2000). The Ban 10 noodles were also characterized for their RS content after all the frying times, using the methodology proposed by Goñi et al. (1996).

Noodles obtained using a time of 90 seconds of deep-frying were characterized for their color using a Hunter Lab colorimeter and for their texture (firmness) using the A/LKB probe with the texturometer TA-XT2 $\mathrm{i}$ (STABLE MICRO SYSTEMS, England). For texture analysis, an optimum cooking time of fried noodles was determined. Rehydration consisted of boiling $10 \mathrm{~g}$ of noodles in $300 \mathrm{ml}$ of distilled water. Optimum cooking time was determined by the point at which the white core disappears when cooked noodle strands are squeezed between a pair of glass plates (PARK; BAIK, 2004).

\section{Statistical analysis}

The results obtained were statistically analyzed by ANOVA and the Tukey test, using the program Statistic 5.0 (Stat Soft, Inc., Tulsa, OK, USA), aiming to identify the existence of significant differences $(\mathrm{p} \leq 0.05)$ between the samples and processes.

\section{RESULTSAND DISCUSSION}

\section{Proximate composition}

Table 1 shows the proximate composition of the wheat flour and the GBF on a wet weight basis. The proximate composition of the wheat flour showed that it had a high carbohydrate content, middle-high protein content and low ash content (Table 1). The moisture content of the wheat flour was $12.61 \%$, within the limits set by Resolution RDC No. 263, September $22^{\text {nd }}, 2005$ of ANVISA (BRAZIL, 2005).

The average value found for GBF fat content was lower than the values reported by other authors, such as Borges et al. (2009) and Fasolin et al., (2007), who found values of $0.68 \%$ and $1.89 \%$ (w.b) respectively. However, the crude protein content was similar to the values found by the authors Borges et al. (2009) and Fasolin et al. (2007), who reported protein contents of $4.5 \%$ and $4.45 \%$, respectively. The average value for the ash content in this study was $3.16 \%$.
Table 1 - Proximate composition of the raw materials (w.b.).

\begin{tabular}{ccc}
\hline Component $(\mathrm{g} / 100 \mathrm{~g})$ & Flour & $\begin{array}{c}\text { Green banana } \\
\text { flour }\end{array}$ \\
\hline Moisture* $^{*}$ & $12.61 \pm 0.07^{\mathrm{a}}$ & $8.91 \pm 0.05^{\mathrm{b}}$ \\
Fat* $^{*}$ & $0.77 \pm 0.005^{\mathrm{a}}$ & $0.36 \pm 0.005^{\mathrm{b}}$ \\
Protein* $^{*}$ & $10.60 \pm 0.065^{\mathrm{a}}$ & $4.99 \pm 0.018^{\mathrm{b}}$ \\
Ash $^{*}$ & $0.56 \pm 0.001^{\mathrm{b}}$ & $3.16 \pm 0.028^{\mathrm{a}}$ \\
Carbohydrates** $^{*}$ & $75.46 \pm 0.01^{\mathrm{b}}$ & $82.58 \pm 0.03^{\mathrm{a}}$ \\
Dietary fiber* $^{*}$ & $2.44 \pm 0.17^{\mathrm{b}}$ & $8.88 \pm 0.10^{\mathrm{a}}$ \\
\hline
\end{tabular}

*Average and standard deviation of four replicates of each analysis.

** Calculated by difference, includes the dietary fiber fraction. Averages with different letters in the same line show significant differences between samples according to the Tukey test $(\mathrm{p}<0.05)$.

The dietary fiber analysis showed a significant difference between the two samples (Table 1). According to the literature, green banana is very rich in carbohydrates and its flour may present $61.3-76.5 \mathrm{~g} / 100 \mathrm{~g}$ of starch (d. b.) and a fiber content of 6.3-15.5 g/100 g (d. b.) (JUAREZGARCIA et al., 2006; MOTA et al., 2000), being the greater part of the starch RS type 2 (RS2).

\section{Resistant Starch Content}

The RS contents of the wheat flour and GBF were $2.13 \pm 0.33 \%$ and $45.70 \pm 0.91 \%$, respectively, and the RS found in the GBF was RS2. RS2 are native uncooked granules of certain starches, such as those of raw potatoes and green bananas, whose crystallinity makes them scarcely susceptible to hydrolysis.

With respect to GBF, the RS content depends on the variety of banana and the method used to obtain the sample. The authors Tribess et al. (2009) found the RS content of the GBF obtained from the Nanicão cultivar (Musa acuminata Cavendish subgroup) to range from 40.9 to $58.5 \%$ on a dry weight basis, depending on the drying conditions (drying temperature and air velocity). OvandoMartinez et al. (2009) reported a value of $42.5 \% \mathrm{RS}$ in the GBF from Musa paradisiaca L., obtained by drying slices of peeled green banana at $50^{\circ} \mathrm{C}$ using a convective heated air dryer.

\section{Color}

The luminosity values for the wheat flour, GBF and Ban10 were $92.36 \pm 0.46,78.12 \pm 0.39$ and $89.90 \pm 0.48$, respectively. In instant noodle production using traditional flour sources, an adequate wheat flour should have a low pigment content $\left(L^{*}\right.$ value $\left.>90\right)$, so such a flour should contain a low ash content, which is usually achieved using 
a low extraction flour. However, when other ingredients are added to the formulation to give functional quality (bran, fiber and other flours) the color of the pasta can become darker, but is nevertheless accepted by consumers.

\section{Polarized light microscopy}

Figure 1 shows the wheat flour and GBF under an optical microscope using normal and polarized light. Optical microscopy under polarized light allows one to see the Maltese Cross of the starch granule. When the starch suspension is heated, some irreversible changes occur in the granules leading to crystallinity and a loss of birefringence. This starch characteristic is very important when processing new types of flour such as GBF, because the drying temperature must be below the gelatinization temperature, in order to maintain the starch properties.
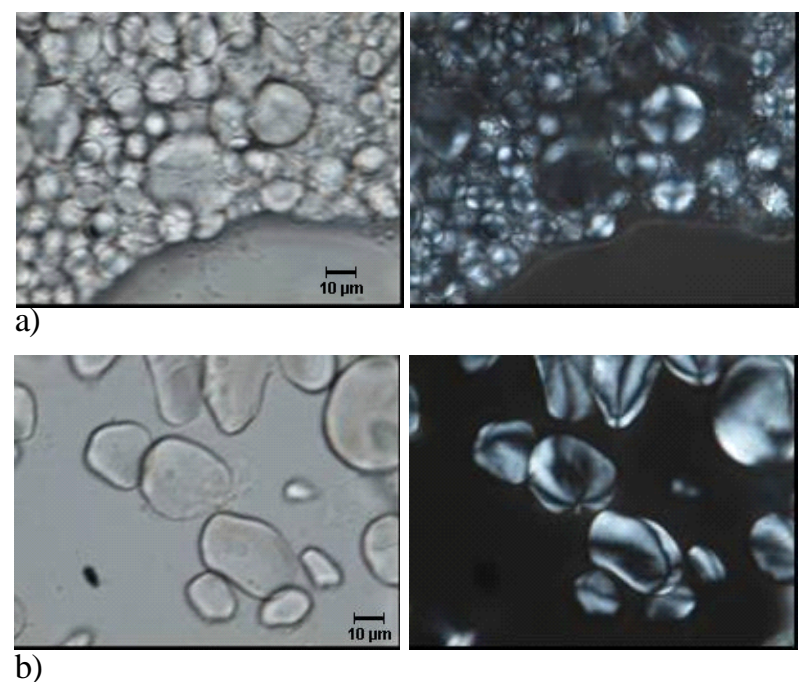

Figure 1 - Optical microscopy under normal and polarized light of (a) wheat flour and (b) green banana flour (x100 magnification).
The starch granules of the wheat flour have a more spherical form than those of the GBF, which are more oval. Moreover, under the microscope one could see that GBF granules were larger in size.

\section{Viscoamylographic properties}

The mean values for the viscoamylographic properties of the wheat flour, GBF and Ban 10 mixture are shown in Table 2. The peak viscosity, final viscosity, breakdown and setback of the three samples were statistically different $(\mathrm{p}<0.05)$, with the highest values being obtained for GBF, with the exception of setback, for which Ban10 showed the highest value, this was probably due to the higher content of dietary fiber.

The GBF suspension showed the highest viscosity and a smaller range for the gelatinization temperature when compared with the other samples. This increase in viscosity indicated that the forces maintaining the structure of the granules were homogeneous. Table 2 also shows a considerable reduction in viscosity (high breakdown value) for the gelatinized GBF paste, indicating high susceptibility to mechanical action and prolonged heating. This could be due to the prevalence of weak linkages in this starch granule, which can be easily destroyed. Moreover, for the wheat flour and Ban10, the increase in viscosity as a function of temperature was smaller, showing that the forces maintaining the granule structure were not homogeneous. On the other hand, this starch showed less susceptibility to mechanical action.

Retrogradation or setback of the GBF showed a higher value when compared to wheat flour. Retrogradation is probably due to aggregation and subsequent insolubilization of the starch molecules.

\section{Rheological Properties}

\section{Farinograph}

Table 3 shows farinograph parameters for the wheat flour and Ban 10 mixture. When GBF was added, Table 3 showed

Table 2 - Viscoamylographic properties of wheat flour, green banana flour and Ban 10 mixture.

\begin{tabular}{cccc}
\hline Parameters* & Wheat flour & Green banana flour & Ban10 \\
\hline Pasting temperature $\left({ }^{\circ} \mathrm{C}\right)$ & $71.22 \pm 1.91^{\mathrm{a}}$ & $72.65 \pm 0.05^{\mathrm{a}}$ & $71.92 \pm 0.56^{\mathrm{a}}$ \\
Peak viscosity $(\mathrm{cP})$ & $2264.00 \pm 0.56^{\mathrm{c}}$ & $6886.50 \pm 34.50^{\mathrm{a}}$ & $2440.33 \pm 71.02^{\mathrm{b}}$ \\
Through viscosity (cP) & $1344.08 \pm 80.32^{\mathrm{b}}$ & $3301.59 \pm 5.77^{\mathrm{a}}$ & $1479.75 \pm 80.32^{\mathrm{b}}$ \\
Final viscosity (cP) $^{\mathrm{b}}$ & $2750.00 \pm 31.58^{\mathrm{c}}$ & $4209.00 \pm 61.22^{\mathrm{a}}$ & $2928.67 \pm 44.77^{\mathrm{b}}$ \\
Breakdown (cP) & $634.00 \pm 89.40^{\mathrm{c}}$ & $3964.50 \pm 29.50^{\mathrm{a}}$ & $943.33 \pm 45.37^{\mathrm{b}}$ \\
Setback $(\mathrm{cP})$ & $1153.33 \pm 40.67^{\mathrm{c}}$ & $1288.67 \pm 56.58^{\mathrm{b}}$ & $1430.67 \pm 59.55^{\mathrm{a}}$ \\
\hline
\end{tabular}

*Average and standard deviation of four replicates of each analysis. Averages with different letters in the same line show significant differences between the samples according to the Tukey test $(\mathrm{p}<0.05)$.

Ciênc. agrotec., Lavras, v. 35, n. 6, p. 1157-1165, nov./dez., 2011 
that water absorption did not change significantly. Other authors have reported that adding RS to the mass does not affect the absorption (ALMEIDA et al., 2010). This parameter is very important due to the optimum water addition during noodle making, when adding GBF did not change the water absorption.

From the data obtained in the farinogram (Table 3), it can be seen that the gluten was diluted and the flour lost its strength with the addition of the GBF. The mixture Ban10 showed lower stability (8.93 $\mathrm{min})$ as compared to the wheat flour (11.87 $\mathrm{min})$ which was to be expected, because the GBF contains other components that may interfere with the gluten network, preventing its continuity, or simply by diluting the proteins found in the wheat flour. This means that the Ban 10 mixture supports a shorter mixture time without destroying the gluten network, i.e. after this time, the gluten quality was reduced. The addition of GBF caused a significant increase in MTI (Table 3). The MTI values for wheat flour and the Ban10 mixture were 34.83 UF and 90.33 UF, respectively, indicating that the addition of GBF decreased the tolerance of the wheat flour to mechanical action during a prolonged mixing time.

\section{Extensograph}

Figure 2 shows the extensograms obtained for the wheat flour and Ban 10 .

Table 3 - Farinograph parameters of the wheat flour and Ban10.

\begin{tabular}{crr}
\hline Parameters* & Wheat flour & \multicolumn{1}{c}{ Ban10 } \\
\hline Water absorption (\%) & $61.47 \pm 0.06^{\mathrm{a}}$ & $61.97 \pm 0.06^{\mathrm{a}}$ \\
Dough development time (min) & $8.50 \pm 0.01^{\mathrm{a}}$ & $8.07 \pm 0.12^{\mathrm{b}}$ \\
Dough breakdown time (min) & $12.17 \pm 0.76^{\mathrm{a}}$ & $10.33 \pm 0.29^{\mathrm{b}}$ \\
Dough stability (min) & $11.87 \pm 0.90^{\mathrm{a}}$ & $8.93 \pm 0.12^{\mathrm{b}}$ \\
Mixing tolerance index (MTI) (UF) & $34.83 \pm 0.29^{\mathrm{b}}$ & $90.33 \pm 0.58^{\mathrm{a}}$ \\
\hline
\end{tabular}

*Average and standard deviation of four replicates of each analysis. Averages with different letters in the same line show significant differences between samples (wheat flour and green banana flour) according to the Tukey test ( $\mathrm{p}<0.05)$.

a)

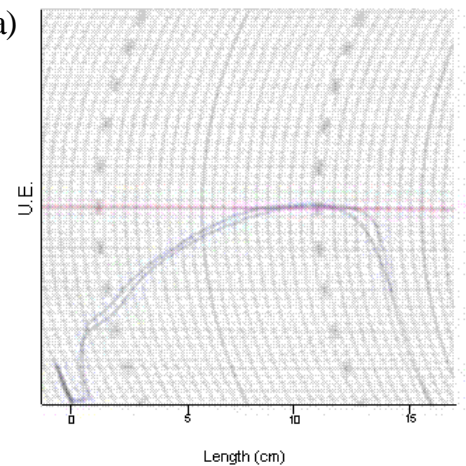

b)

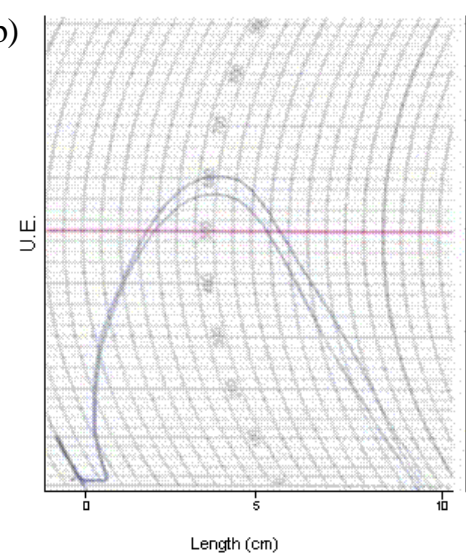

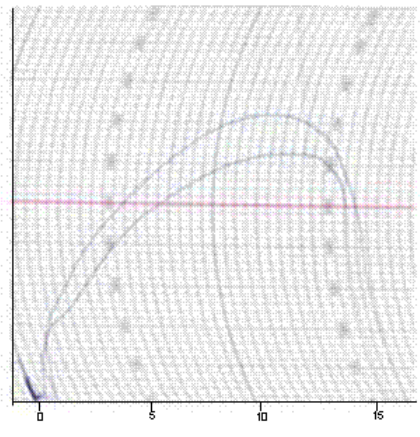

Length (cm)

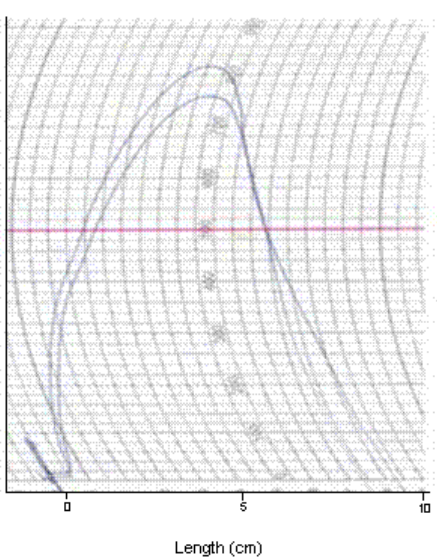

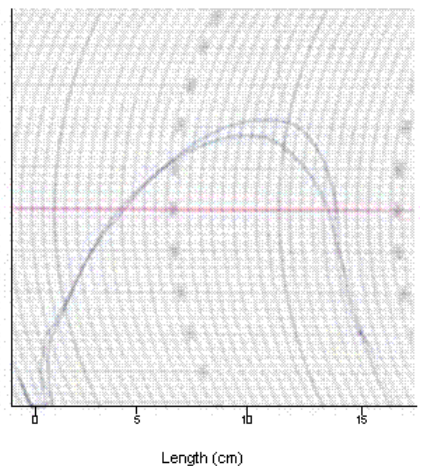

Length (cm)

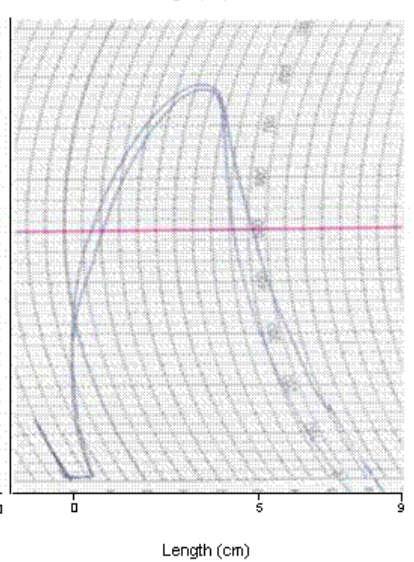

Figure 2 - Extensograph of a) wheat flour and b) Ban10 mixture. 
According to the parameters measured using the extensograph, the Ban10 mixture had significantly higher resistance values to extension, showing the maximum resistance value to extension, and lower extensibility when compared to the wheat flour. Comparing the extensographic parameters for the two samples after $135 \mathrm{~min}$, it was shown that wheat flour had lower values for resistance to extension and maximum resistance to extension, but the extensibility of the wheat flour was significantly higher. This may be due to interference by other compounds from the GBF (fiber, RS) in the dough, resulting in denser, stiffer dough. In agreement with the farinographic parameters, the addition of banana flour to the wheat flour reduced the viscoelastic properties, resulting in weaker, less extensible dough, and it was impossible to add more than $10 \%$ of GFB.

\section{Moisture loss and fat absorption in instant noodle production}

Table 4 shows the moisture and fat contents found in instant noodle production. Moisture loss is very important because the evaporation of water during the deep-frying process produces a particular structure in the instant noodles, since drying by frying is a very fast process. Water vaporizes quickly from the surface of the noodles when immersed in the hot oil $\left(135-160^{\circ} \mathrm{C}\right)$. Dehydration of the external surface causes water to migrate from the interior to the exterior of the noodle strands, resulting in a porous spongy structure (RHO et al., 1986; HOU, 2001).

The fat content of commercial instant noodles is in the range from 16-24\% (WU et al., 2006). In this study, after 30 and 90 seconds of deep-frying, the samples showed significant differences (Table 4). This difference is important, especially after a time of 90 seconds, because this is the optimum time for the deep-frying procedure currently used in the industries. The reduction in fat absorption during the 90s of deep-frying with the Ban10 sample was because of the presence of RS. The reduction in oil absorption in fried products with added RS in the formulation is due to the fact that the RS does not gelatinize at $100^{\circ} \mathrm{C}$, and thus does not absorb water (EERLINGEN; DELCOUR, 1995).

\section{Resistant starch degradation in instant noodle production}

The RS contents obtained after each different step in the instant noodle production process varied from $7.28 \pm$ $0.29 \%$ to $3.90 \pm 0.24 \%$ in the raw sample and the sample fried for $120 \mathrm{~s}$. The RS content in the steamed noodles and in the products after 30,60 and $90 \mathrm{~s}$ of frying were $5.28 \pm$ $0.60 \%, 4.45 \pm 0.75 \%, 4.37 \pm 0.69 \%$ and $3.98 \pm 0.55 \%$, respectively. Analyzing these values, it can be seen that the biggest loss of RS was in the steaming process, where approximately $30 \%$ of RS was lost, whereas after $120 \mathrm{~s}$ of deep-frying, a total of about $46 \%$ was lost. The loss of RS is probably due to its water absorption capacity at high temperatures, where RS acts supposed as a normal starch and loses its physiological properties.

\section{Color of instant noodles}

The values for the luminosity $\left(L^{*}\right)$ and color of the noodles, control and Ban10, were $68.68 \pm 0.91^{\mathrm{a}}$, and $57.40 \pm$ $1.06^{\mathrm{b}}$, respectively. In general, the color parameters are measured as an important feature of product appearance (HOSENEY, 1998). There was a significant difference $(p<0.05)$ between the two samples. The noodles obtained with only wheat flour (control) showed higher values for luminosity $\left(L^{*}=68.68\right)$ than the noodles obtained by adding $10 \% \mathrm{GBF}$ $\left(L^{*}=57.40\right)$. The darkening of the noodles can be attributed to the dark color of the GBF (see section 3.3). The authors Choo and Aziz (2010) also reported a darkening of the color when using GBF in the production of noodles.

Table 4 - Moisture and fat contents obtained after different deep-frying times of the instant noodles.

\begin{tabular}{|c|c|c|c|c|c|}
\hline & \multirow{2}{*}{ Sample } & \multicolumn{4}{|c|}{ Period (s) } \\
\hline & & 30 & 60 & 90 & 120 \\
\hline \multirow{2}{*}{$\begin{array}{c}\text { Moisture* } \\
(\%)\end{array}$} & Control $^{1}$ & $2.31 \pm 0.027^{\mathrm{Aa}}$ & $1.94 \pm 0.157^{\mathrm{Aab}}$ & $1.43 \pm 0.101^{\mathrm{Aab}}$ & $1.42 \pm 0.027^{\mathrm{Ab}}$ \\
\hline & $\operatorname{Ban} 10^{2}$ & $2.89 \pm 0.030^{\mathrm{Ba}}$ & $1.95 \pm 0.089^{\mathrm{Aab}}$ & $1.94 \pm 0.030^{\mathrm{Bbc}}$ & $1.75 \pm 0.053^{\mathrm{Bc}}$ \\
\hline \multirow{2}{*}{$\begin{array}{c}\text { Fat* } \\
(\% \text { b.s. })\end{array}$} & Control $^{1}$ & $22.38 \pm 0.083^{\mathrm{Aa}}$ & $24.11 \pm 0.085^{\mathrm{Ab}}$ & $25.33 \pm 0.074^{\mathrm{Ac}}$ & $26.38 \pm 0.051^{\mathrm{Ad}}$ \\
\hline & $\operatorname{Ban} 10^{2}$ & $21.42 \pm 0.516^{\mathrm{Ba}}$ & $23.90 \pm 0.175^{\mathrm{Ab}}$ & $24.65 \pm 0.076^{\mathrm{Bc}}$ & $26.19 \pm 0.159^{\mathrm{Ad}}$ \\
\hline
\end{tabular}

Ciênc. agrotec., Lavras, v. 35, n. 6, p. 1157-1165, nov./dez., 2011 


\section{Texture}

The values obtained for the firmness of the control and Ban 10 noodles were $89.27 \pm 3.52^{\mathrm{a}}(\mathrm{g})$ and $82.31 \pm 2.31^{\mathrm{b}}$ (g), respectively. The values for firmness of the instant noodles showed significant differences. The addition of $10 \%$ GBF decreased the firmness by an average of $8 \%$. This reduction in firmness can be explained by the decrease in the viscoelastic properties when $10 \%$ of GBF was added to the wheat flour. The addition of GBF reduced the percentage of the wheat proteins (gluten), making it weaker and losing its viscoelastic properties.

\section{Proximate composition of the final products}

Table 5 shows the proximate compositions for the final products, control and Ban10. The fat content in the noodles ranged from 25.7 to $25.1 \%$. The difference in fat content may be due to the RS content of the GBF as explained above. The lower protein content of the Ban 10 noodles was expected, due to the addition of GBF in the noodle formulation, since GBF has lower protein content than wheat flour, as shown in the proximate composition of the raw material. As expected, the remarkable difference in ash contents was due to the materials used in this study. As observed in the proximate compositions of the raw materials (Table 1), the GBF presented more than 5 times more ash than the wheat flour. Finally, the dietary fiber content of the Ban 10 noodles was significantly higher than that of the control noodles. This was due to the high fiber content of the GBF and also because of its high RS content.

Table 5 - Proximate composition (dry weight basis) of the noodles.

\begin{tabular}{ccc}
\hline Component $(\mathrm{g} / 100 \mathrm{~g})$ & Control & \multicolumn{1}{c}{ Ban10 } \\
\hline Fat* $^{*}$ & $25.70 \pm 0.074^{\mathrm{a}}$ & $25.14 \pm 0.076^{\mathrm{b}}$ \\
Protein* $^{*}$ & $10.78 \pm 0.080^{\mathrm{a}}$ & $10.21 \pm 0.070^{\mathrm{b}}$ \\
Ash* $^{*}$ & $0.62 \pm 0.002^{\mathrm{b}}$ & $1.08 \pm 0.004^{\mathrm{a}}$ \\
Carbohydrates** $^{\mathrm{a}}$ & $62.90 \pm 0.03^{\mathrm{b}}$ & $63.57 \pm 0.02^{\mathrm{a}}$ \\
Dietary fiber* & $4.28 \pm 0.09^{\mathrm{b}}$ & $5.79 \pm 0.02^{\mathrm{a}}$ \\
\hline
\end{tabular}

*Average and standard deviation of four replicates of each analysis. ** Calculated by difference, includes dietary fiber fraction. Averages with different letters in the same line show significant differences between samples according to the Tukey test $(\mathrm{p}<0.05)$. 


\section{CONCLUSION}

Although the addition of GBF changed the viscoelastic properties of the dough, due to dilution of the gluten, it was possible to produce noodles with $10 \%$ GBF. Moreover, a slight reduction of fat was observed when GBF was added to the instant noodle formulation. Furthermore, with the addition of $10 \% \mathrm{GBF}$, the product can be claimed to be functional instant noodles, due to the fiber and RS content of the final product.

\section{ACKNOWLEDGMENTS}

The authors thank CAPES-PEC/PG for granting a scholarship to Maria Gabriela Vernaza Leoro and FAPESP (Process number 08/02474-1) for the financial aid provided for the development of this study. The authors also wish to thank Bunge, Agropalma and MasterSense, for their donations.

\section{REFERENCES}

AACC. Approved methods of the American Association of Cereal Chemists (10th ed.). St. Paul: American Association of Cereal Chemists, Inc., 2000.

AOAC. Methods of Analysis, 16th Ed. Int. Assoc. Official Analytical Chemists: Washington, DC., 1995.

ABIMA. Associação Brasileira das Indústrias de Massas Alimentícias, in http://www.abima.com.br/ mercado03.asp., 2005.

ALMEIDA, E.L.; CHANG, Y.K.; STEEL, C.J. Effect of adding different dietary fiber sources on farinographic parameters of wheat flour. Cereal Chemestry. Article In Press. 2010.

BORGES, M.; PEREIRA, J.; LUCENA, M.

Caracterização da farinha de banana verde. Ciência e Tecnologia de Alimentos, Campinas, v.29, n.2, p.333339, abr./jun, 2009.

BRASIL. Ministério da Saúde. Agência Nacional de Vigilância Sanitária (ANVISA). Resolução RDC No 263 de 22 de setembro de 2005 in http://www.e-legis.bvs.br., 2005.

CHAMP, M.; FAISANT, N. Resistant starch: Analytical and physiological aspects. Boletim SBCTA, Campinas, v.30, p.37-43, 1996.
CHOO, C.L.; AZIZ, N.A.A. Effects of banana flour and b-glucan on the nutritional and sensory evaluation of noodles. Food Chemistry, v.119, p.3440, 2010.

EERLINGEN, R. C.; DELCOUR.J.A. Formation, analysis, structure and properties of type III enzyme resistant starch. Journal of Cereal Science, v.22, p.129$138,1995$.

FASOLIN, L.H. et al. Biscoitos produzidos com farinha de banana: avaliações química, física e sensorial.

Ciência e Tecnologia de Alimentos, Campinas, v.27, n.3. p. 524-529, 2007.

GOÑI, I.; GARCIA-DIZ, L.; SAURA-CALIXTO, F. Analysis of resistant starch: a method for foods and food products. Food Chemistry, v.56, p.445-449, 1996.

HOSENEY, R. C. Principles of cereal science and technology. St. Paul: American Association of Cereal Chemists, 1998.

HOU, G.Q. Oriental noodles. Advances in Food and Nutrition Research, v.43, p.141-193, 2001.

ICC. International association for cereal science and technology. Rapid Pasting Method. ICC Standard No. 162, International Association of Cereal Science and Technology, 1995

JUAREZ-GARCIA, E. et al. Composition, digestibility and application in breadmaking of banana flour. Plant Foods for Human Nutrition, v.61, n.3, p.131-137, 2006.

MOTA, R. et al. Composition and functional properties of banana flour from different varieties. Starch/Stärk, Weimheim, v.52, p.63-68, 2000.

PARK, C.S.; BAIK, B.K. Relationship between protein characteristics and instant noodle making: quality of wheat flour. Cereal Chemistry, St. Paul, v.81, p.159-164, 2004.

OVANDO-MARTINEZ, M. et al. Unripe banana flour as an ingredient to increase the undigestible carbohydrates of pasta. Food Chemistry, v.113, p.121126, 2009. 
RHO, K.L.; SEIB, O.K.; CHUNG, D.S. Retardation of rancidity in deep-fried instant noodles. Journal of the American Oil Chemist's Society, v.63, p.251-256, 1986.

TRIBESS, T.B. et al. Thermal properties and resistant starch content of green banana flour (Musa cavendishii) produced at different drying conditions. Food Science and Technology LWT, Switzerland, v.42, p.1022-1025, 2009.

WU, J.; ALUKO, R.E.; CORKE, H. Partial least-squares regression study of the effect of wheat flour composition, protein and starch quality characteristics on oil content of steamed-and-fried instant noodles. Journal of Cereal Science, v.44, p.117-126, 2006. 